\title{
Thermal comfort indexes and physiological parameters of Santa Inês and crossbreed ewes in the semi-arid
}

\author{
Dermeval Araujo Furtado - Francisco Miguel de Melo Oliveira - \\ Wandrik Hauss Sousa - Geovergue Rodrigues Medeiros • \\ Maria Ednalva Cavalcanti Oliveira - Romero Rodrigues Veigas
}

DA Furtado (Corresponding author)

Agricultural Engineering Academic Unit, Universidade

Federal de Campina Grande, PB, Brazil.

email: dermeval.furtado@pq.cnpq.br

GR Medeiros

National Institute of Semi-arid, Brazil.
FMM Oliveira - RR Veigas

City Hall of Campina Grande, PB, Brazil.

WH Sousa - MEC Oliveira

State Agricultural Research Company of Paraíba, PB, Brazil.

Received: July 12, 2016 • Revised: March 21, 2017 • Accepted: March 22, 2017

\begin{abstract}
The objective of this study was evaluated the thermal comfort indexes and physiological parameters in Santa Inês and crossbreed ewes in Brazilian semiarid. The research was developed at experimental station Benjamin Maranhão, twenty non pregnant female sheep were used, 10 pure and 10 crossbreed ( $1 / 2$ Dorper $+1 / 2$ Santa Inês), averaging $26.7 \pm 2.1 \mathrm{~kg}$ and with 150 days of age at the beginning of the study and confined in a covered sheepfold. A completely randomized design in a $2 \times 2$ factorial scheme (two genotypes and two shifts) with four treatments and five repetitions was used. The interior and exterior thermal comfort indexes were, most of the day, above the thermal comfort zone for sheep. The rectal temperature, superficial temperature, respiratory rate and cardiac rate was more elevated in the afternoon, and the Santa Inês animals showed in the mornings low rectal temperature values, as well as superficial temperature, respiratory and cardiac rate when compared to the crossbreed.
\end{abstract}

Keywords: ambience, adaptability, bioclimatology, rectal temperature

\section{Introduction}

The sheep production in the Brazilian semi-arid region is an activity used to produce meat and skins, with predominance in the creation of native animals with no defined racial pattern, highlighting the Santa Inês breeding sheep and their crossbreeds, due to their adaptability to the semi-arid environment (Eustáquio Filho et al 2011; Silva Filho et al 2013; Rocha et al 2014), rusticity, reproductive and productive efficiency (Mori et al 2006 and Jachims et al 2011), and low susceptibility to endo and ectoparasites.
In the Brazilian semi-arid all year round, and especially in the dry season occur high temperatures (Rocha et al 2014), associated with the low relative humidity of the air and the small air movement, and according to Silva (2000) in hot and dry environment occurs evaporation rapidly, causing dermal irritation and general dehydration and in hot and humid environment, evaporation processes slowly, reducing thermolysis and increasing heat stress, mainly because the convolution thermolysis is ineffective when the temperature differential between body surface and the atmosphere. Animals under thermal stress may be limited in development, production and reproduction, also affecting their physiological variables (Oliveira et al 2005; Andrade et al 2007 and Eustáquio Filho et al 2011).

In order to express their productive and reproductive potential, the animals should be kept within the thermal comfort zone (TCZ), which according to Eustáquio Filho et al (2011) the average temperature of $25^{\circ} \mathrm{C}$ and relative humidity of $65 \%$ can be considered as ideal for lambs of Santa Inês breeds with little interference in animals physiological variables.

In the Brazilian semi-arid region, especially in the most critical period of dry season when pasture availability is minimal, it is common for producers to confine the sheep and offer better feed management, so that they maintain their weight, body condition and are fit for reproduction when the time comes. The confinement is also a practice for the recovery of postpartum or low weight females, preparing them for reproduction (Rosa et al 2007, Jochims et al 2011; Rocha et al 2014) or fattening of females for slaughter (Pinheiro et al 2015). In addition to the nutritional management and genotype the comfort of the animals in the facilities has relevant importance, since in the semi-arid the thermal stress can be a limiting factor to sheep reproduction. 
It is a fact that the Santa Inês sheep breed is autochthonous and has excellent adaptability and rusticity to the environmental conditions of the Brazilian semi-arid region. However, the introduction of exotic breeds in the region, specialized for meat production, like Dorper, suggests a generation of knowledge about tolerance and its adaptability to the region to give, according to Cézar et al (2004), the technical background to the introduction of breeds or even guidance of breeding programs, aiming at obtaining types or breeds more appropriate to a specific environmental condition.

This study aimed to evaluate the thermal comfort indexes in the facilities and the physiological variables of Santa Inês breed and Crossbreed sheep ( $1 / 2$ Dorper $+1 / 2$ Santa Inês).

\section{Materials and Methods}

The experiment was carried out at the Experimental Station Benjamim Maranhão belonging to the State Agricultural Research Company of Paraíba - EMEPA-PB, in the municipality of Tacima - PB, located at $06^{\circ} 29^{\prime} 18$ South, $35^{\circ} 38^{\prime} 14^{\prime \prime} \mathrm{W}$, altitude $164 \mathrm{~m}$ in the microregion of Curimataú Oriental, semi-arid region of Paraíba. The region climate is hot and dry with autumn-winter rains and a drought period of five to six months with average precipitation in the period from 2005 to 2015 of $704.34 \pm$ $246.68 \mathrm{~mm}$ (AESA 2016), temperature ranging between 22 and $26^{\circ} \mathrm{C}$ and humidity around $70 \%$.

Twenty sheep were used in this study been ten Santa Inês pure breed and ten crossbreed (Santa Inês and $1 / 2$ Dorper $+1 / 2$ Santa Inês), average age of $150 \pm 20$ days and average weight of $26.7 \pm 2.1 \mathrm{~kg}$ with body condition index (BCI) of 3.0 , confined in a sheep shelter covered with clay tile, $12 \mathrm{~m}$ long, $2.5 \mathrm{~m}$ wide and $2.80 \mathrm{~m}$ height, divided in the middle (where in each bay contains 10 animals), East-West direction, cemented floor with surrounding landscaping with trees where the pre-experimental period was 14 days, so that the animals could adapt the facilities, feeding, management and experimental techniques such as measurement of rectal temperature, respiratory rate, etc., since they were free on the field and the experimental period was thirty days.

During the experimental period were performed every hour, in interval from 7:00 to 17:00, the readings of dry bulb temperature $(\mathrm{Tdb})$, wet bulb temperature $(\mathrm{Twb})$, black globe temperature ( $\mathrm{Tbg}$ ), wind velocity $(\mathrm{V})$, maximum temperature (Tmax) and minimum temperature (Tmin). Inside the sheep shelter, the equipments were located in the center of the animal mass that is $0.70 \mathrm{~cm}$ in height from the floor. On the outside of the sheep shelter, a black globe was exposed to the sun at the same height.

The dry bulb (Tdb) and wet bulb (Twb) temperature data were obtained with Incoterm thermo-hygrometer with a scale of $-10^{\circ}$ to $50^{\circ} \mathrm{C}, 1.0^{\circ} \mathrm{C}$ division and error limit $\pm 1.0^{\circ} \mathrm{C}$. From these data were calculated the relative humidity of the air $(\mathrm{RH})$ and then the temperature of the dew point (Tdp). Relative air humidity was calculated using the equation quoted by Varejão Silva (2000). The black globe temperature was obtained by the aid of black globes made of plastic ball and mercury thermometer, and measured with the help of a standard black sphere with copper sphere inserted in a TGD 200 thermal stress meter of Instrutherm, scale -10 to $150^{\circ} \mathrm{C}$, resolution of $0.1^{\circ} \mathrm{C}$ and precision $\pm 0.5^{\circ} \mathrm{C}$. The wind speed was collected through a portable digital luximeter, Thal-300 model from Instrutherm, with velocity scales of 0.5 to $30.0 \mathrm{~m}$ $\mathrm{s}^{-1}$ and accuracy of $3 \%$. The values of black globe temperature and humidity index (BGHI) were determined using the formula suggested by Buffington et al (1981) and the radiant thermal load (RTL) calculated by the expression quoted by Esmay (1969).

The physiological variables were obtained every four days at 9:00 a.m. and 3:00 p.m., and the rectal temperature was obtained through the introduction of a veterinary clinical thermometer, with scale up to $44^{\circ} \mathrm{C}$, directly into the animal's rectum, at a depth of $5 \mathrm{~cm}$, remaining for a period of 2 minutes. After this time was performed, the reading. Respiratory rate $\left(\mathrm{mov} \mathrm{min}^{-1}\right.$ ) was obtained by direct auscultation of the sounds at the level of the laryngo-tracheal region, counting the movement number for 20 seconds, and the value obtained was multiplied by 3 . Heart rate (mov min ${ }^{1}$ ) was obtained through a veterinary stethoscope counting the number of movements for 20 seconds, and the value obtained was multiplied by 3 . It was used an infrared thermometer, portable mult temp mark, temperature range from -60.0 to $500^{\circ} \mathrm{C}$, accuracy $\pm 2 \%$, resolution of $0.1^{\circ} \mathrm{C}$ to obtain the surface temperature of the animals, and the readings were performed in three animal positions, in the head, in the side and in the legs.

The animals were fed with a diet containing a voluminous: concentrate ratio of $35: 65$. The diet was formulated based on the NRC (2007) to meet the requirements of sheep with live weight of $20 \mathrm{~kg}$, age up to 8 months, late maturity and weight gains of up to 100 grams / day. However, the animals received only 600 grams of dry matter / day of the formulated feed which corresponded to $2.24 \%$ of the live weight. This amount of feed was sufficient to maintain the animals' body condition and to promote the minimum weight gain of the studied ovine females. The ingredients used were Tifton-85 hay (Cynodon dactylon), soybean bran, corn, mineral salt and limestone (Table 1).

It was used a completely randomized experimental design, arranged in a $2 \times 2$ factorial scheme with 4 treatments 5 replications, in which the factors were the two genotypes (Santa Inês and $1 / 2$ Dorper $+1 / 2$ Santa Inês) and two shifts (Morning and Afternoon), to evaluate the environmental and physiological variables of the animals. The data were 
submitted to variance analysis and the means were compared by the Tukey test at 1 and $5 \%$ probability, with computational assistance of the statistical program ASSISTAT, version 7.6 beta (Silva 2011).

Table 1 Percent composition and bromatological composition of experimental diets (\% DM).

\begin{tabular}{lc}
\hline Ingredients & Proportion $(\%)$ \\
\hline Tifton Hay -85 & 35 \\
Corn & 15 \\
Soybean bran & 30 \\
Mineral salt & 15 \\
Calcitic limestone & 5.0 \\
\hline Nutrients (\%) & \\
\hline Dry matter (DM) & 91.18 \\
Crude protein (CP) & 18.7 \\
Ethereal extract (EE) & 1.7 \\
Neutral detergent fiber (NDF) & 35.31 \\
Acid detergent fiber (ADF) & 17.9 \\
Total digestible nutrients (TDN) & 55.2 \\
Calcium (Ca) & 5.75 \\
Phosphor (P) & 2.0 \\
\hline
\end{tabular}

\section{Results and Discussion}

The indoor environment temperature (Table 2) showed a significant effect $(\mathrm{P}<0.01)$ between the morning and afternoon shifts, with the lowest morning temperature, and within the thermal comfort zone (TCZ) for sheep, which according to Eustáquio Filho et al (2011), should be at $25^{\circ} \mathrm{C}$ and the internal temperature in the afternoon was above the TCZ. For external temperature there was a significant effect ( $\mathrm{P}<0.01)$ between the shifts which were above the TCZ. In the afternoon shift it was above the upper critical temperature, which is $35^{\circ} \mathrm{C}$ (Baêta and Souza 2010).

The fact that the indoor temperature environment is lower than the external environment demonstrates the importance of the shading promoted by the coverage of the confinement facility. This is confirmed by Andrade et al (2007) and Oliveira et al (2013) when evaluating the physiological parameters of Santa Inês sheep subjected to shading and exposed to the grazing sun. They concluded that shading provided a reduction in all physiological variables analyzed, mainly in the afternoon, when the environmental conditions were more unfavorable for the animals. On the other hand, animals in high temperature environments, without a cover or protection against direct solar radiation, may have their physiology, zootechnical yield, reproduction and sanity compromised (Oliveira et al 2005; Silva Filho et al 2013).

Table 2 Averages of environmental variables, internal and external in the morning and afternoon periods in the animal's facilities.

\begin{tabular}{lrr|rr}
\hline \multirow{2}{*}{ Environmental variables } & \multicolumn{3}{c}{ Systems } \\
\cline { 2 - 5 } & \multicolumn{2}{c}{ Internal } & \multicolumn{2}{c}{ External } \\
\cline { 2 - 5 } & Morning & Afternoon & Morning & Afternoon \\
\hline Air temperature $\left({ }^{\circ} \mathrm{C}\right)$ & $24.35^{\mathrm{b}}$ & $29.35^{\mathrm{a}}$ & $33.35^{\mathrm{b}}$ & $38.35^{\mathrm{a}}$ \\
Wind speed $\left(\mathrm{m} \mathrm{s}^{-1}\right)$ & $0.30^{\mathrm{b}}$ & $1.30^{\mathrm{a}}$ & $0.73^{\mathrm{b}}$ & $1.73^{\mathrm{a}}$ \\
Relative humidity $(\%)$ & $54.35^{\mathrm{a}}$ & $45.35^{\mathrm{b}}$ & $31.35^{\mathrm{a}}$ & $27.35^{\mathrm{b}}$ \\
Black globe temperature index and humidity & $78.35^{\mathrm{b}}$ & $82.35^{\mathrm{a}}$ & $79.35^{\mathrm{b}}$ & $84.35^{\mathrm{a}}$ \\
Radiant thermal load $\left(\mathrm{W} \mathrm{m}^{-2}\right)$ & $529.35^{\mathrm{b}}$ & $575.35^{\mathrm{a}}$ & $556.5^{\mathrm{b}}$ & $596.35^{\mathrm{a}}$ \\
\hline
\end{tabular}

The means followed by the same letter do not differ statistically from each other. The Tukey test was applied at a 5\% probability level.

Under high temperature animals raise body temperature; the defense mechanisms are intensified and evaporative cooling rises exponentially with increasing internal and external thermal loads. Eustáquio Filho et al (2011) report that, from the air temperature of $25^{\circ} \mathrm{C}$, there is an increase in respiratory rate, rectal, tympanic and peltry temperature, demonstrating the difficulty of sheep in dissipating heat when submitted to high temperatures, where peripheral vasodilation and sweating are activated to dissipate body heat.

It was observed for wind speed values that there was a significant effect $(\mathrm{P}<0.01)$ in the internal and external environment and in the two shifts, been it in the afternoon for both environments, higher than in the morning, but for both 
environments in the morning shift was below that recommended by MacDowel (1972), which should be between 1.3 and $1.9 \mathrm{~m} \mathrm{~s}^{1}$, and in the afternoon was within the ideal, which may favor the convective heat exchange between the animals and the environment. Relative humidity (RH) had a significant effect $(\mathrm{P}<0.01)$ between the environments and shifts, and in both environments the morning RH was higher than that in the afternoon. The ideal relative humidity should be between 50 and $70 \%$ (Baêta and Souza 2010; Eustáquio Filho et al 2011). However, it is observed, mainly during the afternoon shift, that the RH was below the recommended level, which may hinder the latent heat loss of the animals to the environment, especially with a high ambient temperature, as occurred in the present experiment, and animals kept in a warm environment and with low air humidity, skin evaporation occurs rapidly and may cause dehydration in the animals (Silva 2000), causing damages in animal performance.

As for black globe temperature and humidity content (BGHI), there was a significant effect $(\mathrm{P}<0.01)$ between shifts in both environments, with afternoon values higher. According to the National Weather Service of USA, cited by Baêta and Souza (2010) BGHI values up to 74, 74 to 79, 79 to 84 and above 84 , define comfort, alert, danger and emergency situation, respectively. Therefore, it is observed that in the internal and external environment the BGHI in the morning shift was characterized as an environment of alert and danger, respectively, and in the external environment the BGHI was characterized as a dangerous and emergency environment, respectively. Keeping sheep in very stressful environments by the heat may lead the animals to trigger mechanisms of heat loss, both sensitive and latent, with damage to their physiological, productive and reproductive functions.

The material used in the roof of the sheep shelter should be analyzed, as function as its thermal capacity.
Oliveira et al (2005) observed a decrease in the BGHI and CTR in sheep shelter covered with clay tiles compared to asbestos cement tiles, providing better thermal comfort indexes to the sheep confined to these facilities. For the thermal radiation load RTL, it is observed that there was a significant effect $(\mathrm{P}<0.01)$ between shifts in both environments, and in both environments, afternoon shift values were higher.

The rectal temperature of Santa Inês sheep and $1 / 2$ Dorper $+1 / 2$ Santa Inês between the shifts showed a significant difference $(\mathrm{P}<0.01)$ with the highest values in the afternoon (Table 2). According to Silva (2000) to dissipate the thermal energy produced by the metabolism and that received from the external environment, the animal can resort to evaporation or store thermal energy, allowing an increase in the rectal temperature, facts that can be elevated with animals kept under high ET, BGHI and RTL and low $\mathrm{RH}$, such as those recorded in the afternoon. Among the pure and crossbreed animals, it was observed that there was a significant difference $(\mathrm{P}<0.01)$ only in the morning shift, with higher values of crossbreed animals, demonstrating the influence of genetics Dorper breed, of which animals for been more demanding can suffer more from thermal stress.

Although the animals are submitted to environments considered above the TCZ, mainly in the afternoon shift, the means of rectal temperature is within the normal range established for sheep, which according to Dukes and Swenson (1996) can vary from 38.5 to $39.7^{\circ} \mathrm{C}$, showing the good adaptability of these animals to the semi-arid climate, even for Dorper crossbreed. The mean values of RT were similar to those described by Bezerra et al (2011), who studied sheep of different genetic groups in the Paraíba semiarid region, citing a rectal temperature of 38.5 and $39.5^{\circ} \mathrm{C}$ for the morning and afternoon shifts, respectively.

Table 3 Mean of rectal temperature (RT) respiratory rate (RR) and heart rate (HR) in both genetic groups

\begin{tabular}{|c|c|c|c|c|c|c|}
\hline \multirow[b]{2}{*}{$\begin{array}{c}\text { GENETIC } \\
\text { GROUP }\end{array}$} & \multicolumn{2}{|c|}{$\mathrm{RT}\left({ }^{\circ} \mathrm{C}\right)$} & \multicolumn{2}{|c|}{$\mathrm{RR}\left(\mathrm{mov} \mathrm{min}^{-1}\right)$} & \multicolumn{2}{|c|}{$\mathrm{HR}\left(\mathrm{mov} \mathrm{min}^{-1}\right)$} \\
\hline & Morning & Afternoon & Morning & Afternoon & Morning & Afternoon \\
\hline Santa Inês & $38.13^{\mathrm{bB}}$ & $39.50^{\mathrm{aA}}$ & $41.12^{\mathrm{bB}}$ & $49.12^{\mathrm{aA}}$ & $121.37^{\mathrm{bB}}$ & $128.62^{\mathrm{bA}}$ \\
\hline Crossbreed & $38.32^{\mathrm{aB}}$ & $39.42^{\mathrm{aA}}$ & $43.37^{\mathrm{aB}}$ & $49.12^{\mathrm{aA}}$ & $122.37^{\mathrm{aB}}$ & $129.62^{\mathrm{aA}}$ \\
\hline DMS* & \multicolumn{2}{|c|}{0.13} & \multicolumn{2}{|c|}{1.06} & \multicolumn{2}{|c|}{0.76} \\
\hline $\mathrm{CV}(\%)^{* *}$ & \multicolumn{2}{|c|}{0.33} & \multicolumn{2}{|c|}{2.28} & \multicolumn{2}{|c|}{0.59} \\
\hline
\end{tabular}

For respiratory frequency, there was a significant effect $(P<0.01)$ between the morning and afternoon shifts between the genetic groups (Table 2), with those of the afternoon higher. This increase in the RR in this shift is associated with the increase of ET, of the thermal comfort indexes analyzed (BGHI and RTL) and decrease of the RH, causing the animals to use mechanisms of heat loss to the environment through the latent mechanisms. Among the pure 
and crossbreed animals, a significant difference $(\mathrm{P}<0.01)$ was observed in the morning shift, with higher values of the crossbreed animals, demonstrating the influence of Dorper genetics on females. In the afternoon shift the RR values were similar among the genotypes, demonstrating that the environment was more influential in this physiological variable than the genetics.

The values of RR were above the established for the species (Dukes and Swenson 1996), which must be between 12 and $25 \mathrm{mov} \mathrm{min}^{-1}$, but can vary between 16 and $34 \mathrm{mov}$ $\min ^{-1}$, depending, among other factors, on the climate and management system. Eustáquio Filho et al. (2011) reported an increase in the RR on Santa Inês lambs at $30^{\circ} \mathrm{C}$, which were on average $28 \mathrm{mov} \mathrm{min}^{-1}$, rising temperatures at 35 (88 mov $\left.\mathrm{min}^{-1}\right)$ and $40^{\circ} \mathrm{C}\left(172 \mathrm{mov}^{\mathrm{min}^{-1}}\right)$, noting that respiratory rate may be the main form of body dissipation in sheep.

Rocha et al (2014) cite higher values of RR and HR in sheep post-partum sheared in the afternoon shift in relation to the morning shift, both in Morada Nova and Santa Inês sheep. For the maintenance of body temperature, mainly with the meteorological indices and thermal comfort above that required by the animals, the evaporation is indicated as the most efficient way to lose body heat, case in which the breathing and sweating processes are specified as alternatives for the animal (Baêta end Souza 2010).

It was observed that there was a significant difference ( $\mathrm{P}<0.01)$ in sheep heart rate between the shifts (Table 3), with the highest values in the afternoon, similar to those reported by Oliveira et al (2005) and Andrade et al (2007), which describe values of lower heart rate in the morning in relation to the afternoon shift. Among the pure and crossbreed animals, a significant difference $(\mathrm{P}<0.01)$ was observed, with the lowest values for Santa Inês in the two shifts, and this reduction may be associated to the greater adaptability of these animals to the climate of the semi-arid region. Some factors such as environmental conditions, age, excitement, behavior, body mass, physiological status and metabolic rate are related to heart frequency.

Cezar et al (2004) studying the Santa Inês, Dorper and $1 / 2$ Dorper $+1 / 2$ Santa Inês sheep genotypes, with average weights of 18 to $20 \mathrm{~kg}$, in the semi-arid conditions in the State of Paraíba, report mean of HR for the morning shifts 105.67 and 115.3 and 106.6; 115.0 and 111.3 beats per minute for the three genotypes, respectively.

The mean of surface temperature on different animal body regions had a significant effect $(\mathrm{P}<0.01$ ) (Table 4$)$, and the values measured in the afternoon were higher than the morning shift. These results may be associated with the meteorological indexes and thermal comfort used, as well as with the increase in RT, caused by the increase in caloric content, which can cause the animals to produce more heat. Significant difference $(\mathrm{P}<0.01)$ occurred between the Santa Inês breed and its crossbreed with Santa Inês showing the lowest values, demonstrating the adaptability of the animals to the region, where they can maintain a higher thermal gradient between ST and ET, facilitating the heat exchange with the environment.

Table 4 Mean value of head temperature (HT), dorsum (DT) and limb (LT) in two genetic groups.

\begin{tabular}{ccc|cc|cc}
\hline \multirow{2}{*}{ Genotypes } & \multicolumn{2}{c}{$\mathrm{HT}\left({ }^{\circ} \mathrm{C}\right)$} & \multicolumn{2}{c}{$\mathrm{DT}\left({ }^{\circ} \mathrm{C}\right)$} & \multicolumn{2}{c}{$\mathrm{LT}\left({ }^{\circ} \mathrm{C}\right)$} \\
\cline { 2 - 6 } & Morning & Afternoon & Morning & Afternoon & Morning & Afternoon \\
\hline Santa Inês & $32.10^{\mathrm{bB}}$ & $34.10^{\mathrm{bA}}$ & $31.36^{\mathrm{bB}}$ & $34.15^{\mathrm{bA}}$ & $31.16^{\mathrm{bB}}$ & $32.30^{\mathrm{bA}}$ \\
Crossbreed & $33.10^{\mathrm{aB}}$ & $35.10^{\mathrm{aA}}$ & $32.36^{\mathrm{aB}}$ & $35.15^{\mathrm{aA}}$ & $32.16^{\mathrm{aB}}$ & $33.30^{\mathrm{aA}}$ \\
\hline DMS* & \multicolumn{2}{c|}{0.20} & 0.16 \\
\hline CV $(\%)^{* *}$ & \multicolumn{2}{c}{0.610} & 0.48 \\
\hline \multicolumn{2}{c|}{0.32} \\
\hline
\end{tabular}

Eustáquio Filho et al (2011) in sheep research observed a significant linear effect on the fur temperature, which increased with increasing environment temperature, and as it increases, the efficiency of the losses of sensible heat decreased due to the lower temperature gradient between the animal's skin and that of the environment. Andrade et al (2007) in experiments with Santa Inês sheep in the semi-arid region of Paraíba, mentions that thermal comfort indexes were higher in the afternoon, which resulted in higher rectal, superficial, respiratory and cardiac temperature in the animals.
Peripheral vasodilatation increases the surface temperature in animal's body, facilitating the dissipation of heat to the environment, which is dependent on the thermal gradient between the surface temperature of the animals and the environment, and as higher the gradient, the greater is the dissipation of heat. This vasodilation results in a drop in blood pressure and to compensate for this low pressure, there is an increase in cardiac work, therefore, animals kept in warm environments tend to show a significant increase in the frequency of heart beats (Silva, 2000), as occurred in the present experiment (Table 3). 


\section{Conclusions}

The thermal comfort indexes in the interior and exterior of the facilities were above the thermal comfort zone for adult sheep. The rectal temperature, superficial temperature, respiratory and cardiac frequency of the sheep were higher in the afternoon. Santa Inês animals presented lower values of rectal temperature, superficial temperature, respiratory and cardiac frequency in the morning shift in relation to their crossbreed.

\section{References}

AESA. Agência Executiva de Gestão das Águas do Estado da Paraíba. Meteorologia/Chuvas. Monitoramento. http://site2.aesa.pb.gov.br/aesa/monitoramentoPluviometria.do?met odo=listarAnosChuvasAnuais. Accessed in: 20/06/2016.

Andrade IS, Souza BB, Pereira Filho JM, Silva AMA (2007). Parâmetros fisiológicos e desempenho de ovinos Santa Inês submetidos a diferentes tipos de sombreamento e a suplementação em pastejo. Ciência e Agrotecnologia 31:540-547.

Baêta FC, Souza CF (2010). Ambiência em edificações rurais: Conforto animal. Universidade Federal de Viçosa.

Bezerra WMAX, Souza BB, Sousa WH, Cunha MGG, Benicio TMA (2011). Comportamento fisiológico de diferentes grupos genéticos de ovinos criados no semiárido paraibano. Revista Caatinga 24:130-136.

Buffington DE, Colazzo, AA, Canton GM; Pitt D (1981). Black globe humidity index (BGHI), as comfort equation for dairy COWS. Transaction of ASE 24:11-714.

Cézar MF, Souza BB, Souza WH, Pimenta Filho EC, Tavares GP, Medeiros GX (2004). Avaliação de parâmetros fisiológicos de ovinos Dorper, Santa Inês e seus mestiços perante condições climáticas do trópico semi-árido nordestino. Ciência e Agrotecnologia 28:614-620.

Detweiler D. Regulação Cardíaca. In: Swenson MJ, E Reece WO (1996). (Ed.) Dukes: Fisiologia dos animais domésticos. 11 ed. Guanabara Koogan.

Dukes HH, Swenson HJ (1996). Fisiologia dos animais domésticos. 11. Ed. Rio de Janeiro: Afiliada.

Esmay ML (1969). Principles of animal environment. 2.ed. West Port: AVI Publishing. 325p.

Eustáquio Filho A, Teodoro SM, Chaves MA, Santos PEF dos, Silva MWR da, Murta RM, Carvalho GGP de, Souza LEB de (2011). Zona de conforto térmico de ovinos da raça Santa Inês com base nas repostas fisiológicas. Revista Brasileira de Zootecnia 40:1907-1814.

Jochims F, Pires CC, Lins A, Zago LC, Jahn GM, Confortin ACC (2011). Performance of rearing female hoggets under different feeding strategies. Revista Brasileira de Zootecnia 40:1296-1302.

McDowell, R. G (1972). Improvement of livestock production in warm climates. San Francisco: W. H. Freeman and Company.

Mori R, Ribeiro ELA, Mizubuti, IY, Rocha MA da, Silva LDF da (2006). Desempenho reprodutivo de ovelhas submetidas a diferentes formas de suplementação alimentar antes e durante a estação de monta. Revista Brasileira de Zootecnia 35:1122-1128.

NRC (National Research Council). Nutrient Requirements of Small Ruminants (2007). 7th ed. National Academic Press, Washington, DC.

Oliveira FMM de, Dantas RT, Furtado DA, Nascimento JWB, Medeiros AN (2005). Parâmetros de conforto térmico e fisiológico de ovinos Santa Inês, sob diferentes sistemas de acondicionamento. Revista Brasileira de Engenharia Agrícola e Ambiental 9:631-635.

Oliveira FA de, Turco SHN, Borges I, Clemente CAA, Nascimento TVC, Loiola Filho JB (2013). Parâmetros fisiológicos de ovinos Santa Inês submetidos a sombreamento com tela de polipropileno. Revista Brasileira de Engenharia Agrícola e Ambiental 17:10141019.

Pinheiro RSB, Jorge AM, Miranda-de la Lama GC, Souza HBA (2015). Manejo Pré-abate de ovelhas de descarte: perda de peso corporal, qualidade da carne e comportamento animal. Arquivo Brasileiro de Medicina Veterinária e Zootecnia 67:227-234.

Rocha RR da, Oliveira PB de, Nunes AG, Dias STP, Pereira AM, Torreao JNC (2014). Adaptive parameters and thermal comfort of postpartum ewes fed on concetrate supplementation in grazing system. Acta Sientiarum 36: 317-321.

Rosa GT da, Siqueira ER de, Gallo SB, Moraes SSS (2007). Influência da suplementação no pré-parto e da idade de desmama sobre o desempenho de cordeiros terminados em confinamento. Revista Brasileira de Zootecnia 36:953-959.

Silva Filho FP, Azevedo M de, Costa LAB da, Lana AMQ, Ferreira MA, Batista AMV (2013). Heat tolerance index, food intake and weight gain of Santa Inês sheep in the Agreste region of Pernambuco State, Brazil. Acta Scientiarum 35:307-310.

Silva RG (2000). Introdução a Bioclimatologia Animal. São Paulo : Nobel. 286p.

Silva FAS. ASSISTAT - Versão 7.6 beta. Grande-PB: Assistência Estatística, Departamento de Engenharia Agrícola do CTRN Universidade Federal de Campina Grande, Campus de Campina. Disponível em: <http://www.assistat.com>. Accessed in: 22/03/2016.

Varejão Silva, MA (2000). Meteorologia e Climatologia. Gráfica Editora Stilo INMET. Brasília, DF. 